MINERALOGIA, 45, No 1-2: 27-45 (2014)

Original paper

\title{
Mineral carbonation of metallurgical slags
}

\author{
Monika KASINA ${ }^{1 *}$, Piotr R. KOWALSKI ${ }^{1}$, Marek MICHALIK ${ }^{1}$ \\ ${ }^{I}$ Institute of Geological Sciences, Jagiellonian University, Oleandry 2a, 30-063 Krakow, Poland \\ * Corresponding author \\ e-mail:monika.kasina@uj.edu.pl
}

Received: February 16, 2015

Received in revised form: April 20, 2015

Accepted: April 24, 2015

Available online: May 8, 2015

\begin{abstract}
Due to increasing emissions of greenhouse gases into the atmosphere number of methods are being proposed to mitigate the risk of climate change. One of them is mineral carbonation. Blast furnace and steel making slags are co-products of metallurgical processes composed of minerals which represent appropriate source of cations required for mineral carbonation. Experimental studies were performed to determine the potential use of slags in this process. Obtained results indicate that steel making slag can be a useful material in $\mathrm{CO}_{2}$ capture procedures. Slag components dissolved in water are bonded as stable carbonates in the reaction with $\mathrm{CO}_{2}$ from ambient air. In case of blast furnace slag, the reaction is very slow and minerals are resistant to chemical changes. More time is needed for minerals dissolution and release of cations essential for carbonate crystallisation and thus makes blast furnace slags less favourable in comparison with steel making slag.
\end{abstract}

Key-words: blast furnace slag, steel making slag, mineral carbonation, calcite

\section{Introduction}

Global climate change caused by the increasing anthropogenic emission of greenhouse gases (GHGs) into the atmosphere is forcing human kind to lower the net emission of $\mathrm{CO}_{2}$ by reducing global energy use, developing low carbon or carbon-free fuels, or sequestrating $\mathrm{CO}_{2}$ by engineering or natural techniques (Schrag 2007). According to the World Meteorological Organization (WMO 2006), the concentration of atmospheric $\mathrm{CO}_{2}$ has increased by $31 \%$ within the last 150 years, and is still increasing (ca $0.5 \% \mathrm{yr}^{-1}$ ). According 
to the Kyoto Protocol, there is strong interest in stabilising GHGs to mitigate the risk of global warming (Kluger 2007).

One of the ecologically safest method for the binding of $\mathrm{CO}_{2}$ is mineral carbonation. Mineral carbonation is based on the chemical fixation of $\mathrm{CO}_{2}$ in the form of carbonate minerals (Seifritz 1990; Lackner et al. 1995; Mazzotti et al. 2005). It relies on the crystallisation of stable carbonate minerals containing divalent cations $\left(\mathrm{Ca}^{2+}, \mathrm{Mg}^{2+}, \mathrm{Fe}^{2+}\right)$ with $\mathrm{CO}_{2}$ (Lal 2008). The main sources of these cations are naturally occurring silicate minerals (e.g. Lackner et al. 1995). Minerals containing divalent metal cations can be subjected to dissolution, releasing these cations, and as a consequence, the crystallisation of stable carbonates like calcite, dolomite, magnesite or siderite occurs (e.g. Metz et al. 2005; Oelkers et al. 2008). There are two routes for mineral carbonation: in-situ and ex-situ. Insitu carbonation is carried out by injecting $\mathrm{CO}_{2}$ into geological formations rich in silicate minerals, and is similar to the geological storage of $\mathrm{CO}_{2}$, whereas ex-situ carbonation is carried out immediately after the mining and preconditioning of silicates in chemical processing plants or use in industrial wastes; however, this latter process requires additional energy input (Mazzotti et al. 2005; Olajire 2013).

In this study we focus on the determination of the potential use and advisability of slag from iron metallurgy, i.e. steel making slag and blast furnace slag after different times of landfilling for mineral carbonation process. We applied the simple method of lowtemperature wetting and drying as an analogue of processes occurring in nature to indicate that the low-energy and low-cost carbonation method can be effective, as such simple methods of $\mathrm{CO}_{2}$ sequestration could significantly reduce the carbon footprint of manufactured products (e.g. Morales-Flórez et al. 2011).

The simplified reaction of mineral carbonation based on the dissolution of minerals containing divalent cations $(\mathrm{Ca}, \mathrm{Mg}, \mathrm{Fe})$ in the presence of $\mathrm{CO}_{2}$ is shown in (1) below:

$$
\mathrm{MO}+\mathrm{CO}_{2} \rightarrow \mathrm{MCO}_{3}+\text { heat }
$$

where $\mathrm{MO}=\mathrm{CaO}, \mathrm{MgO}, \mathrm{FeO}$. The amount of heat released is dependent on the material that contains the metals and on the specific metal which takes part in the reaction. The heat release during the reaction makes the formation of carbonates thermodynamically favourable at low temperatures (Mazzotti et al. 2005).

The carbonation of calcium, magnesium and iron bearing minerals is common in nature, although it takes place on a geological time scale (Lackner et al. 1995; Lasaga, Berner 1998) and its duration varies in relation to the geological situation. According to a 2005 IPCC report, sandstone or sandstone-shale sequences and mafic/ultramafic rocks are considered as media containing minerals favourable for mineral carbonation. Also rocks containing hydroxylated minerals, such as portlandite $\left(\mathrm{Ca}[\mathrm{OH}]_{2}\right)$ represent favorable substrate (Montes-Hernandez et al. 2012). Nevertheless, industrial waste such as slags and fly ashes are also considered as a mineral source suitable for mineral carbonation (Sipilä et al. 2008; Bodor et al. 2013), especially those materials rich in Ca, i.e. fly ash obtained from lignite combustion (Uliasz-Bocheńczyk et al. 2009), coal-biomass co-combustion (Wilczyńska-Michalik et al. 2009) or biomass combustion (Vassilev et al. 2013).

Despite the fact that these reactions are slow, worldwide accumulated rocks and industrial wastes (e.g. Stolaroff et al. 2005) such as blast furnace and steel making slags, 
which provide minerals rich in divalent cations, can be sufficient for the mineral carbonation of industrial emissions for long periods of time (Goff et al. 2000). Additionally, this reaction can be kinetically enhanced by raising the temperature (O'Connor et al. 2000; Mazzotti et al. 2005) or by decreasing the particle size (O'Connor et al. 2002; Fan, Park 2004). The carbonation of metals from industrial wastes such as blast furnace or steel making slags can be faster than in the case of natural silicates because of the high content of phases rich in $\mathrm{Ca}, \mathrm{Mg}$ or $\mathrm{Fe}$ which are required for carbonate precipitation, as well as low chemical stability of high temperature phases in slag (Férnandez Bertos et al. 2004; Huijgen et al. 2005; Stolaroff et al. 2005; Huijgen et al. 2006). Moreover, industrial residues can be subjected to carbonation directly in the plant where they are produced (Mazzotti et al. 2005).

Carbonation could contribute to the valorisation of waste and production of marketable materials (Salman et al. 2014; Bodor et al. 2013), while the utilisation of energy resulting from the exothermic reaction of carbonation could increase the efficiency of $\mathrm{CO}_{2}$ capture and storage technology (Rasul et al. 2014).

\section{Material and methods}

\subsection{Material and sample preparation}

Steel making slags (SM1, SM2) and blast furnace slags (BF1, BF2) were used after different times of landfilling (Table 1). Slag samples (15 kg each) were ground using a crusher up to ca. $0.4 \mathrm{~cm}$, and then $5 \mathrm{~kg}$ of each sample were milled to the size of $0.2 \mathrm{~mm}$ using a laboratory mill with a bowl of tungsten carbide, and were then mixed to obtain an average composition.

TABLE 1

Landfilling time of different slag samples

\begin{tabular}{lll}
\hline Sample name & Year of production & $\begin{array}{l}\text { Time of landfilling } \\
\text { (in years) }\end{array}$ \\
\hline SM1 & 2002 & 5 \\
\hline SM2 & 2006 & 1 \\
\hline BF1 & 2002 & 5 \\
\hline BF2 & 80, XX century & 25 \\
\hline
\end{tabular}

SM - steel making slag, BF - blast furnace slag. 


\subsection{Experimental procedure}

The experiments were carried out using the "wetting and drying" method. Both type of slags were crushed to $0.4 \mathrm{~cm}$ and milled to $0.2 \mathrm{~mm}$; material from each sample was then used in parallel experiments. $50 \mathrm{~g}$ of each slag sample was subjected to multiple swamping with $400 \mathrm{ml}$ of deionised water in a porcelain evaporating dish. The full experimental cycle was repeated for 21 days, where each cycle lasted for 30 hours and included 24 hours of wetting at room temperature, and 6 hours of drying. The samples were dried under infra-red radiators at a temperature not exceeding $50^{\circ} \mathrm{C}$. Next the experimental powders were prepared for X-ray diffraction (XRD) and chemical analyses by milling them to the fraction $<0.2 \mathrm{~mm}$. Finally, the slag fragments were embedded in resin and polished thin sections were prepared for microscopic analyses.

\subsection{Methods used for material characterisation}

The phase composition, components' size and shape, inner textures, and degree of compactness were described using an optical microscope Nikon Eclipse E600 POL.

Qualitative as well as quantitative analyses of the mineral phases present in the slags both before and after mineral carbonation experiments were determined using XRD. A Philips X'Pert (APD type) diffractometer with a PW 3020 vertical goniometer equipped with curved graphite crystal monochromator were used. $\mathrm{CuK} \alpha$ radiation was used. The qualitative analyses were performed in the analytical range between $2-64^{\circ} 2 \Theta$, step $0.02^{\circ}$, and the time $1 \mathrm{sec} / \mathrm{step}$; whereas for the quantitative analyses the analytical range was 2$70^{\circ} 2 \Theta$ with a step $0.02^{\circ} / 5 \mathrm{sec}$. For the phase identification Philips X'Pert Graphics and Identify software was used. The interpretation of the qualitative results was based on SEIFERT AutoQuan 2.62 (BGMN) software.

Prior to the XRD qualitative analyses, samples were milled using an agate mill down to $0.2 \mathrm{~mm}$ and pressed into the analytical sample holder. For the quantitative XRD analyses, samples were averaged using Retsch Sample Splitters (RT 6.5) and crushed to obtain a grain size $<0.4 \mathrm{~mm} .2 .7 \mathrm{~g}$ of the sample with $0.3 \mathrm{~g}$ of $\mathrm{ZnO}$ as the internal standard were wet milled with the addition of ethanol in a McCrone Micronizing Mill for $10 \mathrm{~min}$ using corundum grinding elements. For weighing the samples, a Radwag AS/60/220/C/2 scale was used. The slurries collected after milling were dried using a WSL LWM8/100 water bath. The dried samples were sieved and prepared as disoriented samples in the analytical cuvettes.

To determine the chemical composition of the minerals and morphology of components, field emission scanning electron microscopy (FE-SEM; Hitachi S-4700 microscope) with energy dispersive spectrometry (EDS) was used. Both the crushed material and polished thin sections were carbon coated, while the analyses were performed at $20 \mathrm{kV}$. The quantitative analyses of the chemical composition were possible by using the EDS spectrometer according to the standardless method. Identification of the elements in spectra, using the analytical Thermo Scientific NSS software, was provided by spot analysis of the chemical composition in the sample. The results were recalculated to $100 \%$.

Chemical analyses of the bulk samples were made using Inductively Coupled Plasma Emission Spectroscopy (ICP-ES) for the main elements' measurement and Inductively 
Coupled Plasma Mass Spectroscopy (ICP-MS) for the trace elements' measurement methods. The analyses were performed in the ACME Analytical Laboratories (Vancouver, Canada). For the analyses, the samples were melted with lithium borate/tetraborate and digested with nitric acid. Loss on ignition (LOI) was determined as a difference in sample weight after ignition at $1000^{\circ} \mathrm{C} . \mathrm{C}_{\text {tot }}$ and $\mathrm{S}_{\text {tot }}$ were determined using the LECO analyser.

\section{Results}

\subsection{Characteristics of steel making slags before the experiment}

The steel making slags are massive, dense, dark-brownish to brown-greyish in colour. The SM2 slag (from 2002) is denser and more massive than SM1 (from 2006). Macroscopically, on the fresh fracture it is possible to recognise elongated larnite crystals and iron oxides. The chemical composition is typical for steel making slag. The dominant components are $\mathrm{CaO}, \mathrm{Fe}_{2} \mathrm{O}_{3}$ and $\mathrm{SiO}_{2}$. However, in $\mathrm{SM} 2$ the $\mathrm{Fe}_{2} \mathrm{O}_{3}$ concentration is significantly higher than in $\mathrm{SM} 1$, whereas the content of $\mathrm{CaO}$ and $\mathrm{SiO}_{2}$ is slightly lower (Table 2). The results of the XRD analyses (Fig. 1, Table 3) indicate that the main phases in steel making slags are larnite $\left(\mathrm{Ca}_{2}\left[\mathrm{SiO}_{4}\right]\right)$, together with srebrodolskite $\left(\mathrm{Ca}_{2} \mathrm{Fe}_{2} \mathrm{O}_{5}\right)$ and wüstite $(\mathrm{FeO})$, and account for $>90 \mathrm{wt} \%$ of both samples. Besides the main phases, lime $(\mathrm{CaO})$, metallic iron $(\mathrm{Fe})$, calcite $\left(\mathrm{Ca}\left[\mathrm{CO}_{3}\right]\right)$ and portlandite $\left(\mathrm{Ca}[\mathrm{OH}]_{2}\right)$ are present in small quantities. The different ratio of larnite to srebrodolskite content is the main difference between the two types of slags differing in time of landfilling.

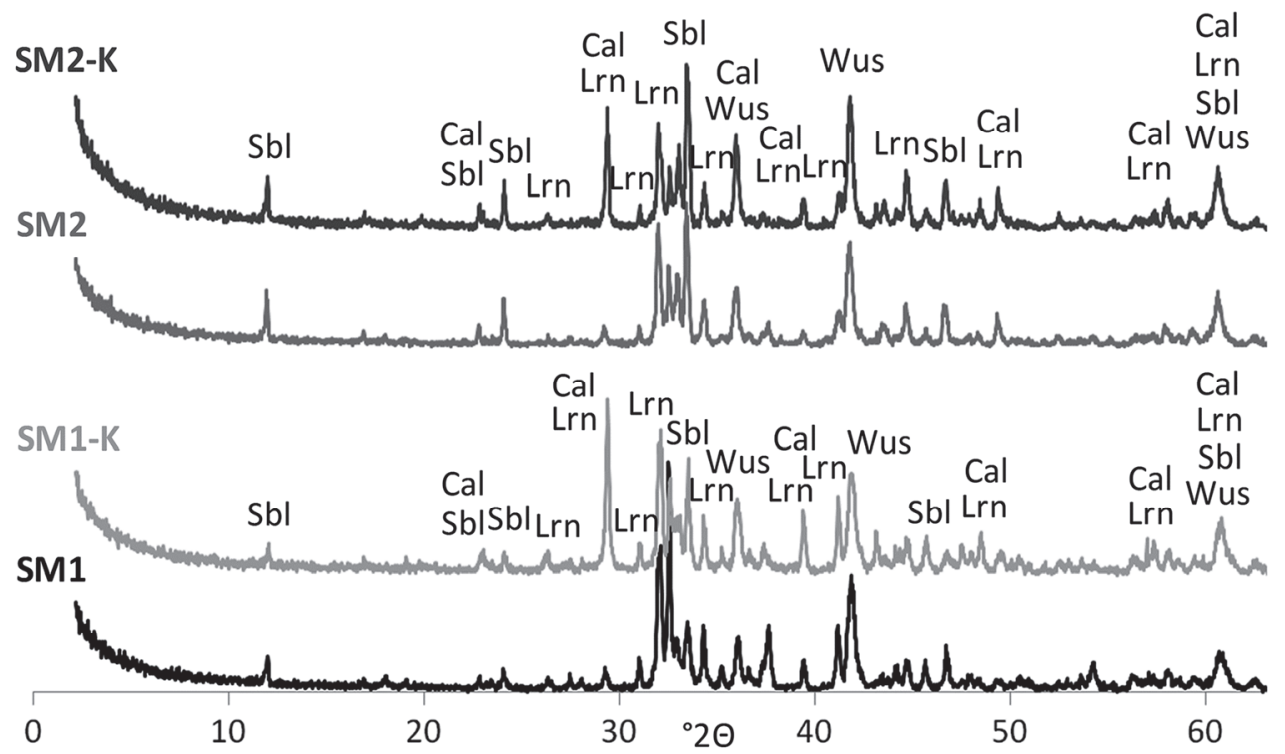

Fig. 1. Results of XRD analysis of steel making slag. SM1, SM2 - raw samples; SM1-K, SM2-K samples after carbonation. Cal - calcite, Lrn - larnite, Sbl - srebrodolskite, Wus - wüstite. Intensities of XRD peaks expressed in counts per second - relative scale. 
TABLE 2

Chemical composition of slag samples before and after experiments (major compounds and selected trace elements)

\begin{tabular}{cllllllll}
\hline & $\mathrm{SM} 1$ & $\mathrm{~S} 11-\mathrm{K}$ & $\mathrm{SM} 2$ & $\mathrm{SM} 2-\mathrm{B}$ & $\mathrm{BF} 1$ & $\mathrm{BF} 1-\mathrm{K}$ & $\mathrm{BF} 2$ & $\mathrm{BF} 2-\mathrm{K}$ \\
\hline $\mathrm{SiO}_{2}$ & 16.51 & 15.11 & 11.33 & 10.00 & 40.93 & 40.98 & 39.12 & 40.22 \\
\hline $\mathrm{Al}_{2} \mathrm{O}_{3}$ & 0.99 & 1.05 & 0.81 & 0.76 & 6.49 & 6.58 & 8.02 & 8.42 \\
\hline $\mathrm{Fe}_{2} \mathrm{O}_{3}$ & 28.29 & 27.10 & 42.79 & 41.36 & 0.32 & 0.26 & 0.73 & 0.50 \\
\hline $\mathrm{MgO}$ & 5.16 & 4.75 & 3.35 & 3.21 & 6.93 & 7.01 & 7.78 & 7.94 \\
\hline $\mathrm{CaO}$ & 47.41 & 42.04 & 39.62 & 37.62 & 43.35 & 41.06 & 40.46 & 39.03 \\
\hline $\mathrm{Na}_{2} \mathrm{O}$ & 0.04 & 0.03 & 0.03 & 0.02 & 0.72 & 0.71 & 0.71 & 0.71 \\
\hline $\mathrm{K}_{2} \mathrm{O}$ & $<0.04$ & $<0.01$ & $<0.04$ & $<0.01$ & 0.69 & 0.65 & 0.42 & 0.42 \\
\hline $\mathrm{TiO}_{2}$ & 0.34 & 0.31 & 0.26 & 0.24 & 0.20 & 0.20 & 0.28 & 0.28 \\
\hline $\mathrm{P}_{2} \mathrm{O}_{5}$ & 0.80 & 0.79 & 1.08 & 1.05 & $<0.01$ & 0.02 & 0.01 & $<0.01$ \\
\hline $\mathrm{MnO}$ & 1.80 & 1.75 & 2.44 & 2.50 & 0.21 & 0.21 & 0.57 & 0.60 \\
\hline $\mathrm{LOI}$ & -1.50 & 6.70 & -2.20 & 2.70 & 0.10 & 2.00 & 1.70 & 1.60 \\
\hline $\mathrm{Sum}$ & 99.84 & 99.63 & 99.51 & 99.46 & 99.94 & 99.68 & 99.80 & 99.72 \\
\hline $\mathrm{S}_{\text {tot }}$ & 0.04 & 0.03 & 0.09 & 0.05 & 0.75 & 0.25 & 0.65 & 0.28 \\
\hline $\mathrm{C}_{\text {tot }}$ & 0.16 & 1.95 & 0.19 & 1.35 & 0.11 & 0.53 & 0.18 & 0.41 \\
\hline & & & & & & & & \\
\hline $\mathrm{Cr}$ & 979.20 & 938.40 & 2400.40 & 2176 & 68.00 & 13.60 & 34.00 & 20.40 \\
\hline $\mathrm{Ba}$ & 295.80 & 260.00 & 91.10 & 90.00 & 659.70 & 615.00 & 605.80 & 611.00 \\
\hline $\mathrm{Sr}$ & 291.70 & 259.40 & 183.60 & 173.40 & 508.90 & 495.90 & 512.50 & 514.40 \\
\hline $\mathrm{V}$ & 299.00 & 269.00 & 585.00 & 557.00 & 5.00 & $<8.00$ & 20.00 & 11.00 \\
\hline $\mathrm{Cu}$ & 17.00 & 15.40 & 13.80 & 13.50 & 0.10 & 0.60 & 0.30 & 0.80 \\
\hline
\end{tabular}

SM - steel making slag, BF - blast furnace slag, $\mathrm{K}$ - samples after carbonation process.

The results of the SEM-EDS observations indicate that larnite occurs in the form of partly automorphic or spindle-shaped crystals, slightly rounded on the edges. The size of crystals varies from several tens to several hundred of microns. Larnite is usually embedded with srebrodolskite, or surrounded by srebrodolskite and wüstite or metallic iron (Fig. 2a). Srebrodolskite plays the role of groundmass in the slag. Srebrodolskite is usually xenomorphic; however, near the vesicles it forms elongated crystals. Srebrodolskite also forms interstitions with iron oxides. Wüstite usually occurs in the form of elongated, thin bands, with the iron content of $64-91 \mathrm{wt} \% \mathrm{FeO}$. It was also possible to detect the presence of $\mathrm{Fe}$ oxides containing $\mathrm{Ca}, \mathrm{Mg}, \mathrm{Mn}$, and $\mathrm{Ca}$ oxides and metallic iron. Metallic iron occurs in the form of irregular inclusions up to $5 \mu \mathrm{m}$ in size. 

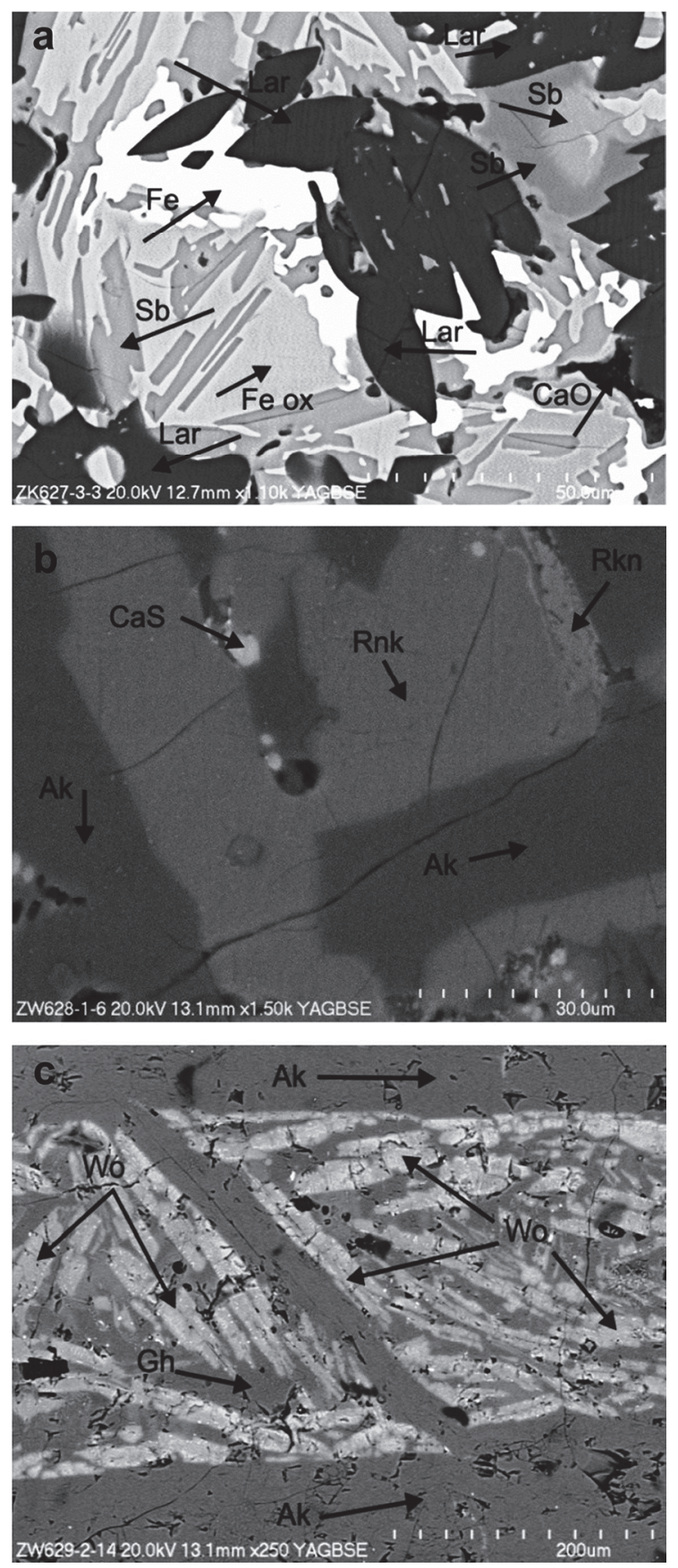

Fig. 2. The overview of main mineral components in slags (SEM-BSE images): (a) - spindle-shaped, slightly rounded on the edges larnite crystals (Lar), surrounded by metallic iron (Fe), Srebrodolskite (Sb), iron oxides (Fe ox) and lime $(\mathrm{CaO})$ are also visible. SM2 - steel making slag; (b) - elongated crystals of akermanite (Ak), surrounding rankinite plate-like crystals (Rnk). BF1 - blast furnace slag; (c) - characteristic intergrowths of gehlenite (Gh) and wollastonite (Wo). BF2 - blast furnace slag. 
Results of XRD quantitative analysis of steel making slags (SM) before and after carbonation process

\begin{tabular}{lllllllll}
\hline Mineral phase & SM1 $(5 \mathrm{yr})$ & $+/-$ & SM1-K & $+/-$ & SM2 $(1 \mathrm{yr})$ & $+/-$ & SM2-K & $+/-$ \\
\hline Larnite & 51.0 & 1.4 & 41.3 & 1.7 & 35.0 & 1.7 & 25.9 & 1.6 \\
\hline Srebrodolskite & 19.8 & 1.1 & 21.3 & 1.5 & 35.9 & 1.2 & 34.7 & 1.2 \\
\hline Wüstite & 19.7 & 0.5 & 21.9 & 0.7 & 20.0 & 0.6 & 24.1 & 0.8 \\
\hline Calcite & 0.8 & 0.8 & 13.4 & 1.4 & 1.4 & 0.4 & 9.2 & 0.8 \\
\hline Fe & 1.7 & 0.2 & 2.2 & 0.3 & 2.8 & 0.3 & 3.3 & 0.3 \\
\hline Portlandite & 0.3 & 0.2 & 0.0 & 0.0 & 0.8 & 0.3 & 0.0 & 0.0 \\
\hline Lime & 6.7 & 0.4 & 0.0 & 0.0 & 3.2 & 0.4 & 0.0 & 0.0 \\
\hline
\end{tabular}

(X yr) - time of slag landfilling. $\mathrm{K}$ - samples after carbonation process. Values in wt\%.

\subsection{Characteristics of steel making slags after mineral carbonation}

The chemical composition of the steel making slags (SM1 and SM2) after the carbonation experiment has not change significantly in comparison with the raw sample (Table 2). The content of the major components as $\mathrm{CaO}, \mathrm{Fe}_{2} \mathrm{O}_{3}, \mathrm{SiO}_{2}, \mathrm{Al}_{2} \mathrm{O}_{3}$ and $\mathrm{MgO}$ is lower than prior to the experiment, which is related to a significant increase of the LOI value (Table 2). Also, the content of $\mathrm{C}_{\text {tot }}$ is higher (Table 2). Changes in the content of minor elements such as $\mathrm{Ba}, \mathrm{Sr}, \mathrm{V}, \mathrm{Ni}$, and $\mathrm{Cu}$ were also measurable (Table 2). The mineral composition of steel making slags after the experiments in general remained the same (Fig. 1, Table 3), and only lime and portlandite were not present. The carbonation process did not have an influence on the srebrodolskite and wüstite content, but the larnite content decreased to about $9.1-9.8 \mathrm{wt} \%$ in both samples. A significant increase in calcite content was measured: in the SM1 sample from $0.8 \mathrm{wt} \%$ to $13.4 \mathrm{wt} \%$ and in $\mathrm{SM} 2$ from $1.4 \mathrm{wt} \%$ to $9.2 \mathrm{wt} \%$. Detailed XRD quantitative data are shown in Table 3.

Besides the changes present in the slag material after the experiments, newly formed calcite crystallised on the surface of the evaporating dish together with a small amount of fine fraction washed out from the slag. The calcite concentration reached on average $\sim 95 \mathrm{wt} \%$; however, detailed quantitative analyses were not performed because of the limited amount of material. The calcite formed encrustations on the slag fragments up to 0.1-0.2 mm thick. It also crystallised inside the slag fragments forming nests or as porelining material (Fig. 3a, b).

SEM-EDS studies indicate that larnite and srebrodolskite occur as sharp-edged grains covered by xenomorphic secondary material, with chemical composition is similar to the composition of the mineral on the surface of which it crystallises. However, often this material is a complex mixture of the components which undergo dissolution and precipitation during the experiment. Typical is the presence of calcite or other forms of calcium carbonate that form different crystals: crust-like, bush-like, but rarely in the rhombohedral form. The mineral components in the slag post-experiment were not 
subjected to visible transformation related to mineral carbonation; however significant changes, especially the modification in larnite composition, were observed in the near edge of each fragment (Fig. 4a). Noteworthy, in this case, is the significant accumulation of $\mathrm{P}_{2} \mathrm{O}_{5}$ and $\mathrm{FeO}$, and the increased $\mathrm{C}$ peak in the EDS spectrum. Rims $(\sim 25 \mu \mathrm{m})$, with a composition similar to "altered larnite" around the edges of the slag fragments were noted. The pore spaces, which originally were rimmed by calcium oxides, were completely filled with calcite after the experiment. Moreover, the calcite also crystallised as rims ( $\sim 30 \mu \mathrm{m}$ thick) along the edges of the slag fragments.
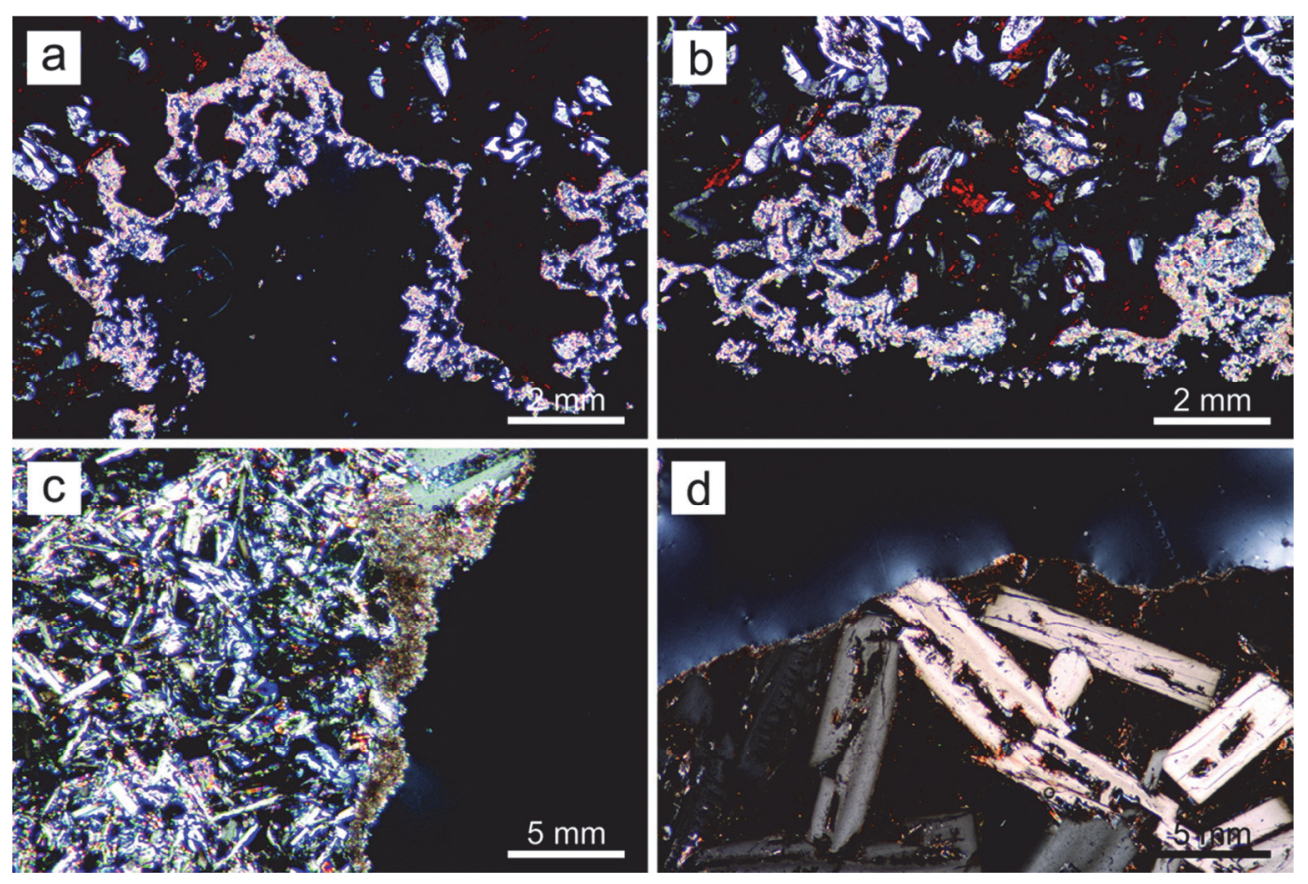

Fig. 3. Summary of carbonation process: $(a, b)$ - edges of slag fragments rimmed by thin layer of calcite, which penetrates sample deeply (steel making slag); (c) - slag fragments rimmed by thin layer of calcite (process visible only on edges); (d) - slag fragments smooth and not rimmed (blast furnace slag). Polarising microscopy - crossed polars.

\subsection{Characteristics of blast furnace slags before the experiment}

The blast furnace slags BF1 and BF2 are vesicular and light grey in colour. They are characterised by low density because of the high amount of vesicles of variable size (from $0.5 \mathrm{~cm}$ up to several $\mathrm{cm}$ in diameter). Macroscopically, it is difficult to recognise any slag components; however, it is possible to note secondary gypsum in the vesicles. The chemical composition of the studied slag samples is shown in Table 2. The dominant components are $\mathrm{CaO}$ and $\mathrm{SiO}_{2}$, while the content of $\mathrm{Al}_{2} \mathrm{O}_{3}$ and $\mathrm{MgO}$ is lower. The content 

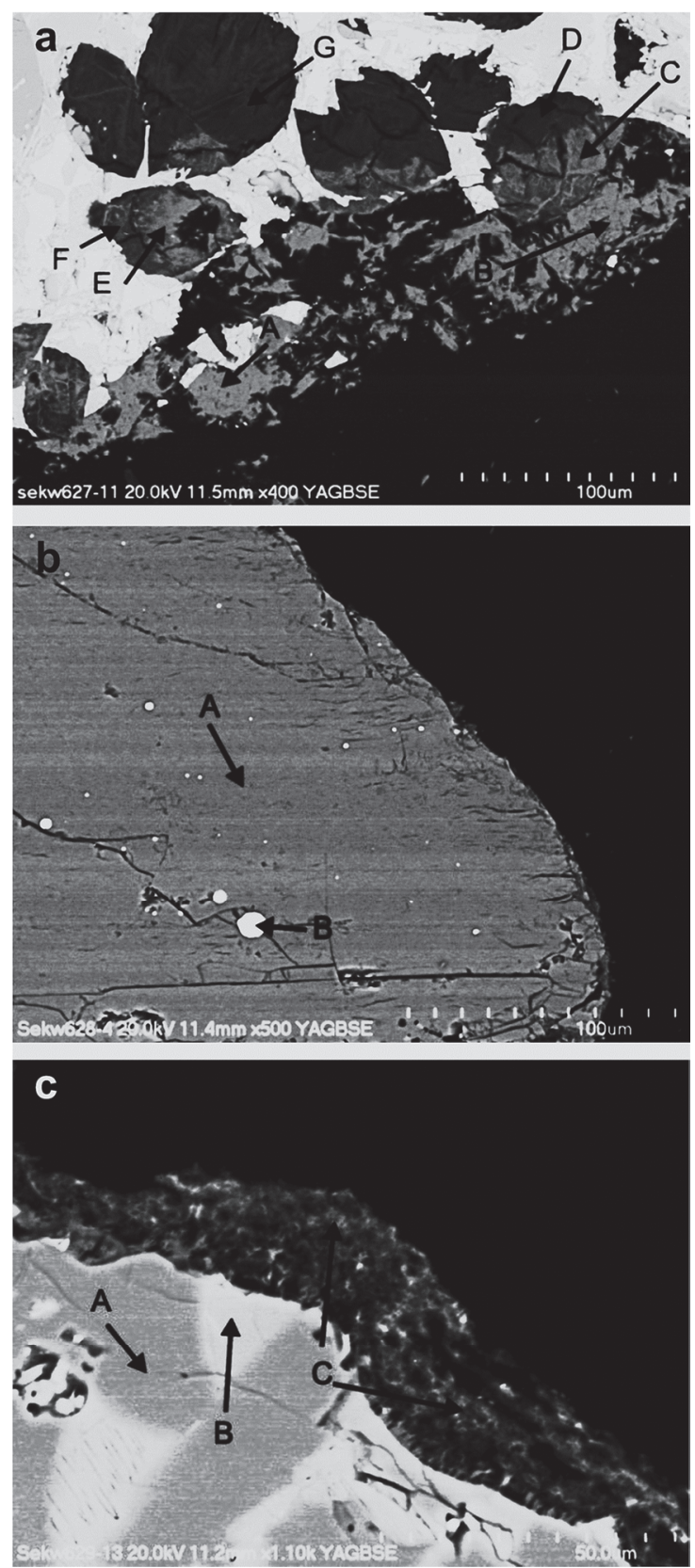

Fig. 4. The edges of the slag fragments (SEM-BSE images): (a) - along which crystallized calcite (A and B) and different "stages" of larnite transformation (mineral is being replaced with a material rich in phosphorus) (C, D, E, F, G). SM2 - steel making slag; (b) - the smooth edge of the blast furnace slag after the experiment of mineral carbonation. Large crystals of akermanite (A) and metallic iron drop (B) are visible. BF2 - blast furnace slag; (c) - the rim around slag fragment edge, composed of calcium and sulphur rich phase (probably gypsum) (C). A - elongated crystals of gehlenite. B wollastonite. BF2 - blast furnace slag. 
of the other components is not higher than $1 \mathrm{wt} \%$. The results of the XRD analyses indicate the presence of melilite group minerals: akermanite $\left(\mathrm{Ca}_{2} \mathrm{Mg}\left[\mathrm{Si}_{2} \mathrm{O}_{7}\right]\right)$ and gehlenite $\left(\mathrm{Ca}_{2} \mathrm{Al}_{2}\left[\mathrm{SiO}_{7}\right]\right)$, together with wollastonite $\left(\mathrm{Ca}\left[\mathrm{SiO}_{3}\right]\right)$ as the main phases in the blast furnace slags $(80 \mathrm{wt} \%$ in $\mathrm{BF} 1,92 \mathrm{wt} \%$ in $\mathrm{BF} 2)$. Besides the main phases, rankinite $\left(\mathrm{Ca}_{3}\left[\mathrm{Si}_{2} \mathrm{O}_{7}\right]\right)$ (only in the $\mathrm{BF} 1$ sample), larnite $\left(\mathrm{Ca}_{2}\left[\mathrm{SiO}_{4}\right]\right)$ and in very small quantities calcite are present. Detailed XRD quantitative data are shown in Table 3.

Akermanite in SEM-EDS usually occurs as a groundmass component or in the form of elongated crystals of about $50 \mu \mathrm{m}$ in size. Inclusions of metallic iron and $\mathrm{CaS}$ within akermanite often occur. Rankinite is present in the form of laths with the size of several dozen of microns (Fig. 2b). Gehlenite is often present in the form of lamellar subhedral or anhedral crystals. It is less common than akermanite, and usually in smaller sizes, up to $10 \mu \mathrm{m}$. The formation of gehlenite intergrowths with wollastonite (Fig. 2c) is common, while wollastonite occurs as skeletal plates with slightly curved edges. Using SEM-EDS it was possible to also detect other slag components such as perovskite $\left(\mathrm{Ca}\left[\mathrm{TiO}_{3}\right]\right)$, single examples of manganese sulphide $(\mathrm{MnS})$, titanite $\left(\mathrm{CaTi}\left[\mathrm{SiO}_{5}\right]\right)$, lime $(\mathrm{CaO}), \mathrm{Cr}-\mathrm{Ni}$ alloys and also some unidentified phases.

\subsection{Characteristics of blast furnace slag after mineral carbonation}

The chemical composition of the blast furnace slags after the experiment is similar to the slag composition of the raw material (Table 2). The major components are $\mathrm{CaO}$ and $\mathrm{SiO}_{2}$, whereas $\mathrm{Al}_{2} \mathrm{O}_{3}$ and $\mathrm{MgO}$ are present in lower amounts. Only a slight decrease in $\mathrm{CaO}$ content was noted. A decrease in the $\mathrm{S}_{\text {tot }}$ content and increase in $\mathrm{C}_{\text {tot }}$ and LOI was also determined; however, it is much lower than in the case of the steel making slags.

According to the XRD results, the mineral phases present in the samples after the experiment are similar to those found in the initial samples (Fig. 5). There are no significant changes in the content of almost all minerals (Table 4). Changes were observed in the content of rankinite in the BF1 sample, which was 3.5\% lower after the experiment, and also in the calcite content. In both samples small increases were observed, from $0.4 \mathrm{wt} \%$ to $2.2 \mathrm{wt} \%$ and from $0.6 \mathrm{wt} \%$ to $2.6 \mathrm{wt} \%$ in the $\mathrm{BF} 1$ and $\mathrm{BF} 2$ samples, respectively. Detailed XRD quantitative data are shown in Table 4 . The XRD analyses were also performed on the material, which was leached from the slag sample BF2 during wetting and re-deposited on the surface of the evaporating dish. In BF1 very poor precipitation was observed $(<0.05 \mathrm{~g})$; therefore, the XRD analyses were possible only for BF2. Detailed quantitative characterisation was not possible, and only approximate results can be presented. In this material fine fraction from the slag and elevated content of calcite are present, composed of $\sim 55 \mathrm{wt} \%$ akermanite, $24 \mathrm{wt} \%$ gehlenite, $10 \mathrm{wt} \%$ larnite, $7 \mathrm{wt} \%$ calcite and $4 \mathrm{wt} \%$ wollastonite.

In the SEM images the minerals are xenomorphic, with visible traces of dissolution in the form of etch pits on the surface or their edges; however, their composition after experiment does not change. Careful optical microscopy and SEM-EDS study indicate that the calcite (or other carbonates) formation is very limited. The edges of the slag fragments are smooth (Fig. 4b), and devoid of secondary carbonate (Fig. 3c, d). 


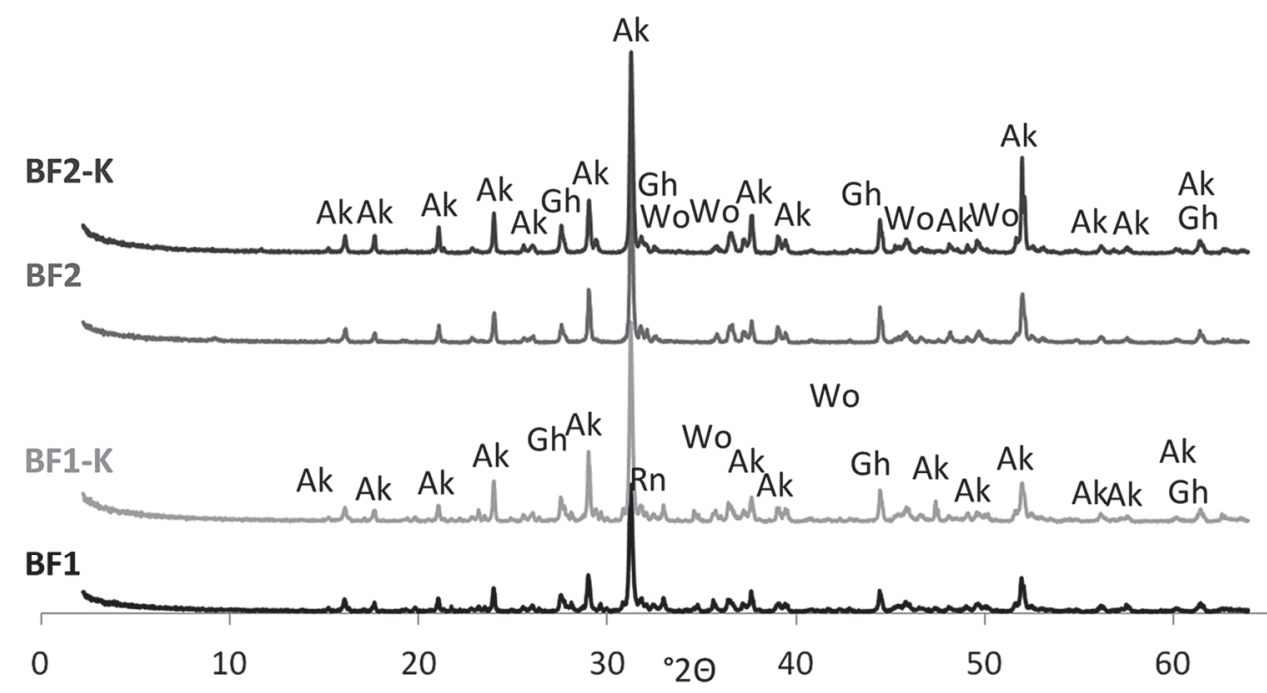

Fig. 5. Results of XRD analysis of blast furnace slag with description of main mineral phases. BF1, BF2 - raw slag samples; BF1-K and BF2-K - slag samples after carbonation. Ak - akermanite, Gh - gehlenite, Rnk - rankinite, Wo - wollastonite. Intensities of XRD peaks expressed in counts per second - relative scale

TABLE 4

Results of XRD quantitative analysis of blast furnace slags (BF) before and after carbonation process

\begin{tabular}{lllllllll}
\hline Mineral phase & BF1 $(5 \mathrm{yr})$ & $+/-$ & BF1-K & $+/-$ & BF2 $(25 \mathrm{yr})$ & $+/-$ & BF2-K & $+/-$ \\
\hline Akermanite & 42.2 & 2.2 & 43.0 & 3.0 & 49.8 & 2.5 & 51.5 & 2.5 \\
\hline Wollastonite & 23.9 & 2.3 & 24.9 & 3.6 & 24.8 & 2.1 & 23.8 & 2.0 \\
\hline Gehlenite & 13.9 & 1.7 & 13.8 & 2.3 & 17.5 & 2.0 & 16.1 & 2.0 \\
\hline Rankinite & 11.9 & 1.1 & 8.4 & 1.1 & 0.0 & 0.0 & 0.0 & 0.0 \\
\hline Larnite & 7.6 & 1.2 & 7.7 & 1.2 & 7.4 & 1.1 & 6.1 & 1.2 \\
\hline Calcite & 0.4 & 0.4 & 2.2 & 0.4 & 0.6 & 0.3 & 2.6 & 0.4 \\
\hline
\end{tabular}

(X yr) - time of slag landfilling. K - samples after carbonation process. Values in wt\%.

Sometimes it is possible to observe the calcium carbonate rims; however, their size does not exceed several micrometres (rarely tens), and very often they are contaminated with the accumulation of sulphur, which indicates the formation of secondary gypsum $\left(\mathrm{Ca}\left[\mathrm{SO}_{4}\right] \cdot 2\left(\mathrm{H}_{2} \mathrm{O}\right)\right)($ Fig. $4 \mathrm{c})$.

\section{Discussion}

The carbonation of steel making slag was relatively effective. The calcite content increased in SM1 from $0.8 \mathrm{wt} \%$ to $13.4 \mathrm{wt} \%$ and in SM2 from $1.4 \mathrm{wt} \%$ to $9.2 \mathrm{wt} \%$ (Table 3 
and Fig. 1). Secondary calcite precipitated on and inside the slag fragments, and on the walls of the evaporating dish. Carbonation influenced the results of the chemical analyses (increase of LOI values, increase of $\mathrm{C}_{\text {tot }}$ and related decrease of content of other components), while the carbonation process also affected larnite: its content was over $9 \%$ lower after the experiment. The complete dissolution of $\mathrm{Ca}$ oxides and hydroxides during the carbonation experiment was noted. The carbonation was more effective in the SM1 sample where the portlandite and lime content was higher $(7 \mathrm{wt} \%)$, than in SM2 where the content of these compounds was lower ( $3 \mathrm{wt} \%$ ) (Table 3 and Fig. 6$)$.

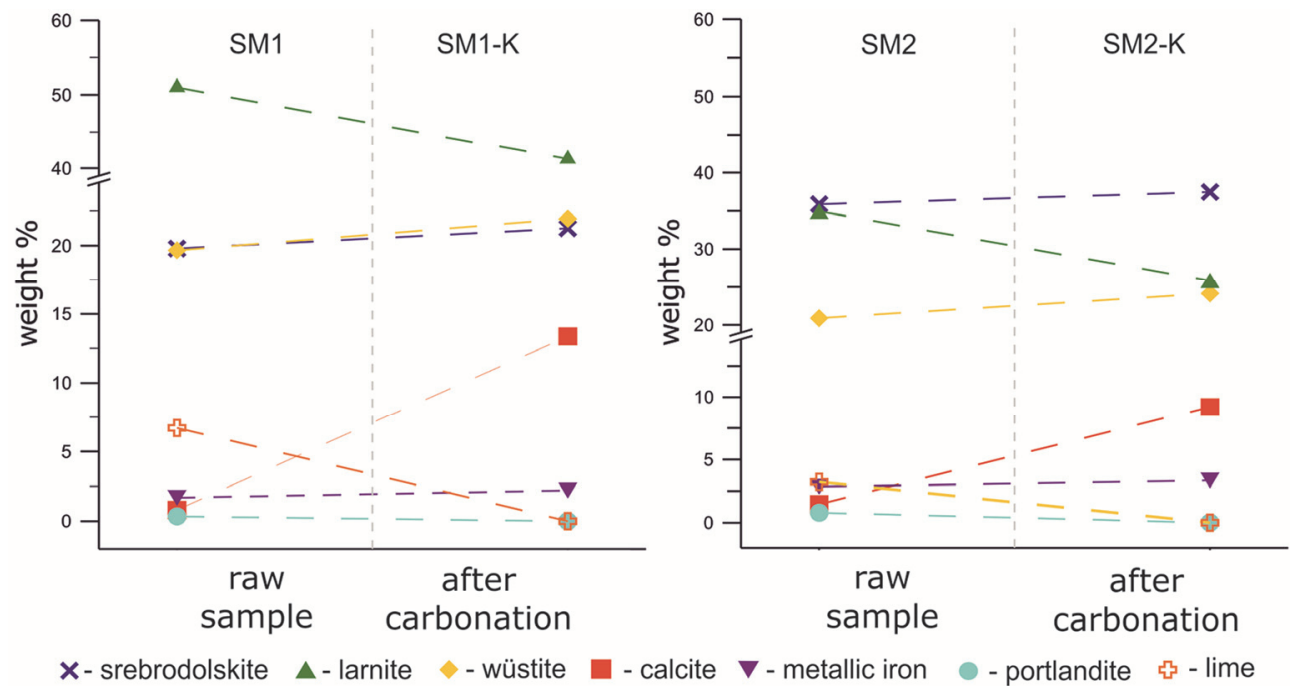

Fig. 6. Changes in mineral content due to effective mineral carbonation experiment in comparison to the raw slag based on the XRD quantitative analyses. SM1, SM2 - steel making slags after different time of landfilling.

The results of the qualitative and quantitative XRD analyses of the powdered samples after the experiment indicate that the studied blast furnace slags were not very reactive and were relatively resistant to mineral carbonation, although the content of divalent cations (Ca and $\mathrm{Mg}$ ) was similar to the steel making slag. After the experiment only slight changes in the calcite content were observed. In the BF1 sample the calcite content increased from $0.4 \mathrm{wt} \%$ to $2.2 \mathrm{wt} \%$, and in the BF2 sample from $0.6 \mathrm{wt} \%$ to $2.6 \mathrm{wt} \%$. Also, as in the steel making slag, the carbonation process affected the silicate minerals. The content of the rankinite in BF1 was $\sim 3.5 \mathrm{wt} \%$ lower after the experiment (Fig. 7).

The results obtained using the SEM-EDS on slag fragments indicate that both types of material (steel making and blast furnace slag) were subjected to the mineral carbonation process. However in case of the blast furnace slag, this process was not very advanced. Single calcite crystals formed rims ( $\sim 25 \mu \mathrm{m}$ thick) around the slag edges, but the most common component that crystallised on the edges was gypsum, or the slag edges preserved without any changes during the experiment. In the case of the steel making slag, the mineral carbonation process was more advanced. Calcite crystallised not only as a rim around the 
slag edges, but also infilled pore spaces that were empty before the experiment (or were rimed by Ca oxides).

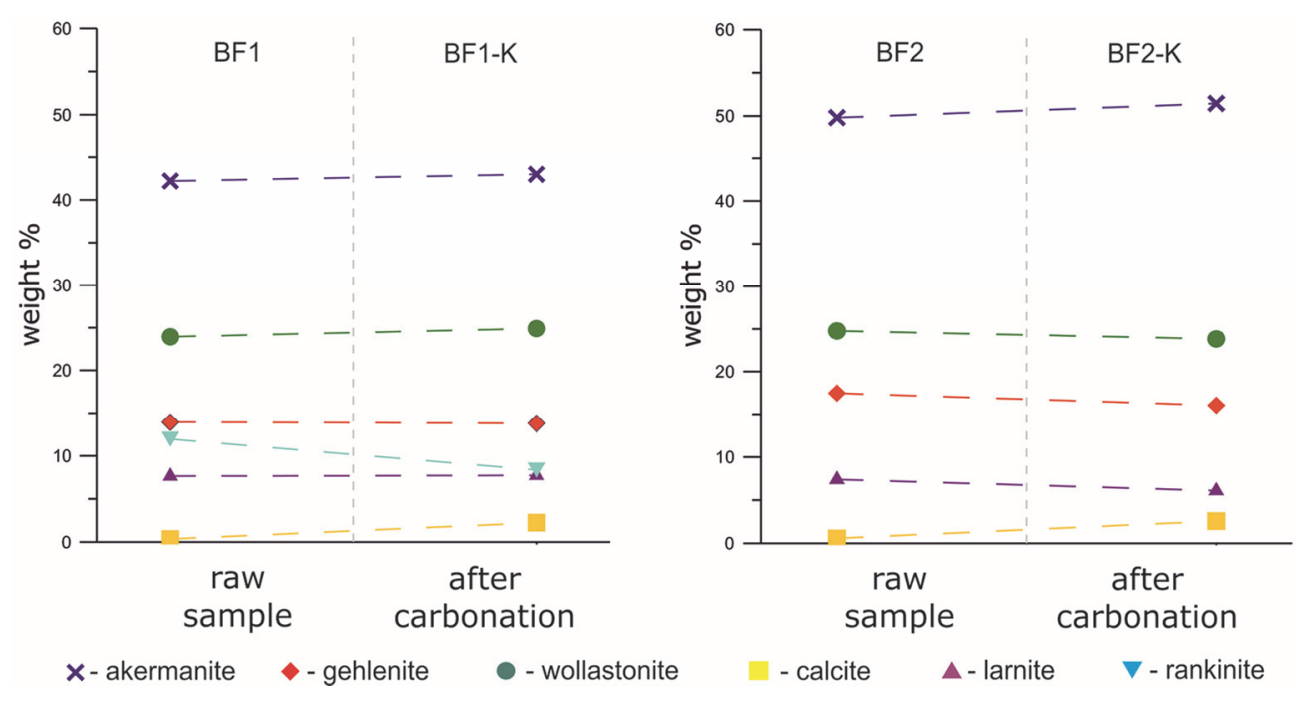

Fig. 7. Changes in mineral content due to ineffective experiment of mineral carbonation in comparison to the raw slag based on the XRD quantitative analyses. BF1, BF2 - blast furnace slags after different time of landfilling.

Even though in both types of slags the concentration of $\mathrm{CaO}$ and $\mathrm{MgO}$ was similar, the carbonation process was not very effective in the case of the blast furnace slags. It was mostly related to the different mineral composition and different solubility of the mineral components, in the blast furnace slags dominated by the melilite group minerals and in the steel making slags by the dicalcium silicates and calcium ferrites. According to Engström et al. (2014), the dissolution rate of silicate minerals present in the slag is $\mathrm{pH}$ dependent, being lower at higher $\mathrm{pH}$. A high $\mathrm{pH}$ value $(\sim 11)$ is typical for this material. Already at $\mathrm{pH} 10$, the dissolution of the melilite group minerals is very low. The $\mathrm{pH}$ value measurement of the solution before and after experiment was neglected due to high variations caused by waterslag interaction during the experiment, constant dissolution and release of components to the solution, variation in solution concentration due to rapid evaporation and therefore in our case this estimation cannot be confirm. Hardly any carbonation was observed in the blast furnace slags. The larnite was very susceptible to dissolution. The steel making slag samples contained portlandite and lime (which were determined by XRD quantitative and SEM-EDS analyses) which are relatively soluble. These phases were absent in the blast furnace slag samples.

We assumed that the dissolution of larnite during carbonation leads to the release of $\mathrm{SiO}_{2}$, but no quartz precipitated because the concentration of $\mathrm{SiO}_{2}$ was still below the saturation level. The release of $\mathrm{SiO}_{2}$ led to the formation of calcium depleted silicate rims, mostly composed of $\mathrm{Si}$ (amorphous $\mathrm{SiO}_{2}$ ), at the slag edges around the newly formed calcite. The alteration rims represent a residue containing phosphate and silica composed of $50 \mathrm{wt} \%$ of $\mathrm{SiO}_{2}$, up to $40 \mathrm{wt} \%$ of $\mathrm{CaO}$ and up to $20 \mathrm{wt} \%$ of $\mathrm{P}_{2} \mathrm{O}_{5}$. SEM-EDS analyses of this 
material also indicate high carbon content. Theoretically, the solid solution $\beta-\mathrm{Ca}_{2}\left[\mathrm{SiO}_{4}\right]-$ $\mathrm{Ca}_{3}\left[\mathrm{P}_{2} \mathrm{O}_{8}\right]$ (Chaurand et al. 2006) with larnite can be linked between orthosilicates and orthophosphates (Fix et al. 1969). In addition, $\mathrm{P}$ can often be bonded with $\mathrm{Si}$ in silicate minerals. As a result of the larnite dissolution during the experiment, $\mathrm{P}$ and $\mathrm{Si}$ were released, and as a consequence accumulated and crystallised near the slag fragment edges. Similar residue coated rims were also observed in the studies of Huijgen and Comans (2006), van Zomeren et al. (2011), and Morone et al. (2014). Rims rich in Si can act as passivating layers coating slag fragments and prohibiting the progress of carbonation (e.g. Bodor et al. 2013; Sanna et al. 2014).

Calcite rims formed around the slag fragments during carbonation also result in a lowering of the carbonation reaction rate because of the insulating of unreacted fragments from the solution. This problem could be solved by decreasing the slag fragments' size (milling before carbonation), through dispersion of the slag fragments by sonication during carbonation (Santos et al. 2013), or other methods.

One of the essential conditions for the occurrence of carbonation is the dissolution rate of slag components in water (Diener et al. 2010). $\mathrm{Ca}, \mathrm{Mg}, \mathrm{Sr}, \mathrm{Ba}$ ions may precipitate as carbonates in the presence of $\mathrm{CO}_{2}$ formed from ambient air (Huijgen, Comans 2006). If the precipitation of the carbonate occurs, the concentration of these elements relatively decreases. This might be the reason why the content of $\mathrm{Ca}$, but also $\mathrm{Mg}, \mathrm{Fe}, \mathrm{Ba}$ or $\mathrm{Sr}$ decreases after carbonation in most of the samples, especially in SM slags (Table 2). Usually $\mathrm{Mg}$ occurs in melilite-group minerals, although mostly in akermanite (in blast furnace slag) or in Fe-oxides (wüstite in steel making slag), which are not prone to dissolution. Due to low $\mathrm{Mg}$ concentration and low experimental temperature $\mathrm{Mg}$ carbonates precipitation was unfavourable, as also suggested by Saldi et al. (2009).

Reduction in the rate of metal ( $\mathrm{Ca}, \mathrm{Ba}$ or $\mathrm{Sr}$ ) release due to dissolution was expected due to the $\mathrm{pH}$ decrease after carbonation (Walton et al. 1997). Theoretically the Mg content should also decrease, in the same proportion as in the case of $\mathrm{Ca}$; however, this relation was not observed.

The release of elements like $\mathrm{Si}$ or $\mathrm{V}$ is common in slags subjected to carbonation. Huijgen and Comans (2006) and Drissen (2007) observed the increase of vanadium content in samples which underwent carbonation, as a result of the dissolution of calcium silicate minerals containing $\mathrm{V}$. The release of elements is typical for silicate minerals subjected to natural weathering processes. In general, the volume of elements subjected to this process is not high; therefore, their influence on the environment is very low (Diener et al. 2010). The release of minor elements such as $\mathrm{As}, \mathrm{Cd}, \mathrm{Co}, \mathrm{Cu}, \mathrm{Hg}, \mathrm{Ni}, \mathrm{Pb}$ or $\mathrm{Zn}$ is also very low, mostly related to the fact that their content in the slag is low, usually close to the detection limits of an applied analytical method. The content of $\mathrm{Ca}$ and $\mathrm{Sr}$ decreases with the increase of $\mathrm{Mg}$, $\mathrm{Si}$ and $\mathrm{V}$ leaching. Mineralogical changes recognised using XRD include calcite formation. Further mineralogical changes (precipitation of different carbonate minerals, changes in the structure of silicate minerals) are also possible (Diener et al. 2010); however, due to the limitation of the methods used they were not detected.

Although the results of previous studies on the use of blast furnace slag in the process of mineral carbonation were satisfactory (e.g. Pu et al. 1988), the results obtained during the wet and dry experiments indicate that silicate minerals, which can be a source of divalent cations, are weakly reactive, which is associated with a lower rate of dissolution of the 
components. The dissolution is a long-term process. Therefore, more time is required to release cations that can take part in carbonate precipitation.

It was possible to observe significant changes in the LOI. The primary negative values of LOI in steel making slags were associated with the oxidation of Fe. The increase in the LOI for SM1, SM2 and BF1, and the decrease in LOI in BF2 were measured. Also, the increase in $\mathrm{C}_{\text {tot }}$ was measured respectively for SM1, SM2, and BF1. These changes were especially significant in the steel making slags. This could be attributed to the carbonation process, which is responsible not only for changes in chemical, but also in mineral composition. A distribution of $\mathrm{C}_{\text {tot }}$ to LOI ratio indicates the increase of the carbonate ion associated with the carbonation of slag together with the increase of appreciation of LOI in the case of steel making slag. This dependency was poorly outlined in the blast furnace slags from 2002 (BF1), and not noted for slags landfilled for 25 years (BF2) (Fig. 8); therefore, we assume that the period of time spent in landfill does not influence the efficiency of the carbonation process.

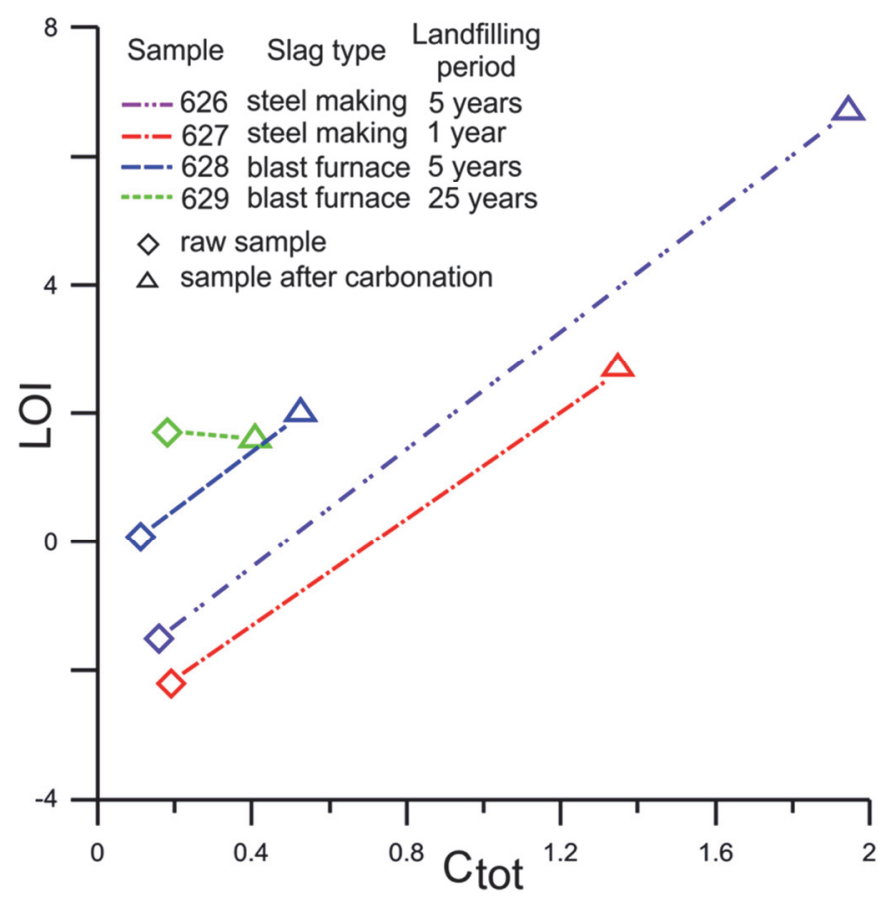

Fig. 8. Distribution $\mathrm{LOI} / \mathrm{C}_{\mathrm{tot}}$ ratio for steel making slags and blast furnace slags.

Mineral carbonation using steel making slag seems to be a promising and economical method of $\mathrm{CO}_{2}$ capture and storage (Huijgen et al. 2005; Tier et al. 2005). The results could be considered as a simulation of the processes occurring in nature during repeated cycles of wetting during atmospheric precipitation and subsequent drying. The results indicate that this method of carbonation gives acceptable effects without application of any special installations, reagents and additional energy except of the crushing and milling of the slag 
before reaction. It is possible to improve the effectiveness of the process, but a detailed calculation of costs is needed. Crystallisation of calcite in slag can be considered as a method of modification of slag properties opening new application fields for this material (e.g. in the production of building materials).

\section{Conclusions}

1. Carbonation of iron metallurgy slag (blast furnace and steel making slag) was tested using the wetting and drying method with uptake of $\mathrm{CO}_{2}$ from the ambient air. The results indicate that carbonation is effective in the case of steel making slag, and thus it can be considered as a useful material for the capture and storage of $\mathrm{CO}_{2}$.

2. The degree of carbonation is related to the mineral composition of the slag. The content of relatively soluble components releasing divalent elements is the most important factor. The total content of divalent elements (similar in both slag types) is a factor of lower importance.

3. Detail observations of slag fragments after the carbonation experiment indicate that the silica-rich layer which formed around the slag fragments and calcite (or calcite-gypsum) coatings reduces the effectiveness of carbonation (formation of passivating layer).

4. Mineral carbonation of slag is a promising environmental development since it can involve waste material. Using slags in this process can directly lead to the clearing of land where slags have been landfilled, and thus can also limit the potential threat of soil and water pollution. Utilisation of carbonated slag can be considered as an additional advantage.

Acknowledgements. The study was supported from the Jagiellonian University research found (DS) and Lesser Poland Doctoral Scholarship, funded by 2.6 Regional innovation strategies and transfer of knowledge of Integrated Regional Operational Programme 20042006 (2009) - European Social Fund 2009. Special thanks to the company Slag Recycling Sp. z o.o. for providing the slag samples for analysis.

\section{References}

Bodor, M., Santos, R. M., van Gerven, T., \& Vlad, M. (2013). Recent developments and perspectives on the treatment of industrial wastes by mineral carbonation - a review. Central European Journal of Engineering, 3 , 566-584. DOI: 10.2478/s13531-013-0115-8.

Chaurand, P., Rose, J., Domas, J., \& Bottero, J-Y. (2006): Speciation of Cr and V within BOF steel slag reused in road construction. Journal of Geochemical Exploration, 88, 10-14.

Diener, S., Andreas, L., Herrmann, I., Ecke, H., \& Lagerkvist, A. (2010). Accelerated carbonation of steel slags in a landfill cover construction. Waste Management, 30, 132-139.

Drissen, P. (2007). Binding of trace elements in steel slags. In: Proceedings of the Fifth European Slag Conference (Euroslag). 19-21 September 2007 (pp. 187-198). Luxembourg.

Engström, F., Adolfsson, D., Samuelsson, C., Sandström, Å., \& Björkman, B. (2013). A study of the solubility of pure slag minerals. Minerals Engineering, 41, 46-52. DOI: 10.1016/j.mineng.2012.10.004.

Fan, L. S. \& Park, A. (2004). $\mathrm{CO}_{2}$ mineral sequestration in a high pressure, high temperature, 3-phase fluidized bed reactor. Canadian Journal of Chemical Engineering, 81(3-4), 885-890.

Férnandez Bertos, M., Simons, S. J. R., Hills, C. D., \& Carey, P. J. (2004). A review of accelerated carbonation technology in the treatment of cement-based materials and sequestration of $\mathrm{CO}_{2}$. Journal of Hazardous Materials, B112, 193-205. 
Fix, W., Heymann, H., \& Heinke, R. (1969). Subsolidus relations in the system $2 \mathrm{CaO} \cdot \mathrm{SiO}_{2}-3 \mathrm{CaO} \cdot \mathrm{P}_{2} \mathrm{O}_{5}$. Journal of the American Ceramic Society - Discussion and Notes, 52, 346-347.

Goff, F., Guthrie, G., Lipin, B., Fite, M., Chipera, S., Counce, D., Kluk, E., \& Ziock, H. (2000). Evolution of ultramafic deposits in eastern U.S. and Puerto Rico as sources of magnesium for $\mathrm{CO}_{2}$ sequestration. LA13328-MS, Los Alamos National Laboratory, Los Alamos, NM, USA.

Huijgen, W. J. J., \& Comans, R. N. J. (2006). Carbonation of steel slags for $\mathrm{CO}_{2}$ sequestration: leaching of products and reaction mechanism. Environmental Technology, 40, 2790-2796.

Huijgen, W. J. J., Witkamp, G-J., \& Comans, R. N. J. (2005). Mineral $\mathrm{CO}_{2}$ sequestration by steel slag carbonation. Environmental Science and Technology, 39, 9676-9682.

Huijgen, W. J. J., Witkamp, G. J., \& Comans, R. N. J. (2006). Mechanisms of Aqueous Wollastonite Carbonation as a Possible $\mathrm{CO}_{2}$ Sequestration Process. Chemical Engineering Science, 61, 4242-4251.

Kluger, J. (200). Global warming: what now? Our feverish planet badly needs a cure. (2007, April 9) Time Magazine, 9, 50-109.

Lackner, K. S., Wendt, C. H., Butt, D. P., Joyce, E. L. Jr., \& Sharp, D. H. (1995). Carbon dioxide disposal in carbonate minerals. Energy, 20, 1153-1170.

Lal, R. (2008): Sciences Carbon sequestration. Philosophical Transactions of The Royal Society London B Biological, 363(1492), 815-830.

Lasaga, A. C., \& Berner, R. A. (1998). Fundamental aspects of quantitative models for geochemical cycles. Chemical Geology, 145(3-4), 161-175.

Mazzotti, M., Abanades, J. C., Allam, R., Lackner, K. S., Meunier, F., Rubin, E., Sanchez, J. C., Yogo, K., \& Zevenhoven, R. (2005). Mineral carbonation and industrial uses of carbon dioxide In IPCC Special Report on Carbon Dioxide Capture and Storage. Edited by Metz, B. Davidson, O. de Coninck, H. Loos, M. Meyer, L. Intergovernmental Panel on Climate Change 2005. New York: Cambridge University Press.

Metz, B., Davidson, O., de Coninck, H., Loos, M., \& Meyer, L. (eds) (2005). IPCC Special Report on Carbon Dioxide Capture and Storage (pp. 431). New York: Cambrige University Press , 431.

Montes-Hernandez, G., Daval, D., Findling, N., Chiriac, R., \& Renard, F. 2012. Linear growth rate of nanosized calcite synthesized via gas-solid carbonation of $\mathrm{Ca}(\mathrm{OH}) 2$ particles in a static bed reactor. Chemical Engineering Journal, 180, 237-244.

Morales-Flórez, V., Santos, A., Lemus, A., \& Esquivias, L. (2011). Artificial weathering pools of calcium-rich industrial waste for $\mathrm{CO}_{2}$ sequestration. Chemical Engineering Journal, 166, 132-137. DOI: 10.1016/j.cej.2010.10.039.

Morone, M., Costa, G., Polettini, A., Pomi, R., \& Baciocchi, R. (2014). Valorization of steel slag by a combined carbonation and granulation treatment. Minerals Engineering, 59, 82-90. DOI: 10.1016/j.mineng.2013.08.009.

O’Connor, W. K., Dahlin, D. C., Nilsen, D. N., Rush, G. E., Walters, R. P., \& Turner, P. C. (2000). CO 2 storage in solid form: A study of direct mineral carbonation. In: Proceedings of the 5th International Conference on Greenhouse Gas Technologies. 13-16 August 2000 (pp. 322-327). Cairns, Australia: CSIRO Publishing.

O’Connor, W. K., Dahlin, D. C., Rush, G. E., Dahlin, C. L., \& Collins, W. K. (2002). Carbon dioxide sequestration by direct mineral carbonation: process mineralogy of feed and products. Minerals and Metallurgical Processing, 19(2), 95-101.

Oelkers, E. H., Gislason, S. R., \& Matter, J. (2008). Mineral carbonation of $\mathrm{CO}_{2}$. Elements, 4, 333-337.

Olajire, A. A. (2013). A review of mineral carbonation technology in sequestration of $\mathrm{CO}_{2}$. Journal of Petroleum Science and Engineering, 109, 364-392. DOI: 10.1016/j.petrol.2013.03.013.

Pu, X. C., Gan, C. C., Wang, S. D., \& Yang, C. H. (1988). Summary Reports of Research on Alkali-Activated Slag Cement and Concrete, v.1-6, Chongqing Institute of Architecture and Engineering, Chongqing (1988).

Rasul, M. G., Moazzem, S., \& Khan, M. M. K. (2014). Performance assessment of carbonation process integrated with coal fired power plant to reduce $\mathrm{CO}_{2}$ (carbon dioxide) emissions. Energy, 64, 330-341. DOI: 10.1016/j.energy.2013.09.047.

Saldi, G. D., Jordan, G., Schott, J., \& Oelkers, E. H., 2009. Magnesite growth rates as a function of temperature and saturation state. Geochimica Cosmochimica Acta, 73, 5646-5657.

Salman, M., Cizer, Ö., Pontikes, Y., Santos, R. M., Snellings, R., Vandewalle, L., Blanpain, B., \& van Balen, K. (2014). Effect of accelerated carbonation on AOD stainless steel slag for its valorization as a $\mathrm{CO}_{2}$ sequestering construction material. Chemical Engineering Journal, 246, 39-52. DOI: 10.1016/j.cej.2014.02.051.

Sanna, A., Lacinska, A., Styles, M., \& Maroto-Valer, M. M. (2014). Silicate rock dissolution by ammonium bisulphate for $\mathrm{pH}$ swing mineral $\mathrm{CO}_{2}$ sequestration. Fuel Process Technology, 120, 128-135. DOI: 10.1016/j.fuproc.2013.12.012. 
Santos, R. M., François, D., Mertens, G., Elsen, J., \& van Gerven, T. (2013). Ultrasound-intensified mineral carbonation. Applied Thermal Engineering, 57, 154-163. DOI: 10.1016/j.applthermaleng.2012.03.035.

Schrag, D. P. (2007). Preparing to capture carbon. Science, 315, 812-813. DOI: 10.1126/science.1137632.

Seifritz, W. (1990). $\mathrm{CO}_{2}$ disposal by means of silicates. Nature, 345, 486.

Sipilä, J., Teir, S., \& Zevenhoven, R. (2007). Carbon dioxide sequestration by mineral carbonation. Literature review updates 2005-2007. Report VT 2008-1.

Stolaroff, J. K., Lowry, G. V., \& Keith, D. W. (2005). Using CaO- and MgO-rich industrial waste streams for carbon sequestration. Energy Conversion and Management, 46, 687-699.

Tier, S., Eloneva, S., \& Zevenhoven, R. (2005). Production of precipitated calcium carbonate from calcium silicates and carbon dioxide. Energy Conversion and Management, 46, 2954-2979.

Uliasz-Bocheńczyk, A., Mokrzycki, E., Piotrowski, Z., \& Pomykała, R. (2009). Estimation of $\mathrm{CO}_{2}$ sequestration potential via mineral carbonation in fly ash from lignite combustion in Poland. Energy Procedia, 1, 48734879. DOI: 10.1016/j.egypro.2009.02.316.

Vassilev, S. V., Baxter, D., Andersen, L. K., \& Vassileva, C. G. (2013). An overview of the composition and application of biomass ash. Part 2. Potential utilisation, technological and ecological advantages and challenges. Fuel, 105, 19-39. DOI: 10.1016/j.fuel.2012.10.001.

Walton, J. C., Bin-Shafique, S., Smith, R., Guitierrez, N., \& Targuin, A. (1997). Role of carbonation in transient leaching of cementitious wasteforms. Environmental Science \& Technology, 31, 2345-2349.

Wilczyńska-Michalik, W., Gasek, R., Dańko, J., \& Michalik, M. (2009). Fly ash from coal and biomass cocombustion and its role in $\mathrm{CO}_{2}$ sequestration. Mineralogia Special Papers, 35, 114.

WMO, 2006: Greenhouse gas bulletin: the state of greenhouse gases in the atmosphere using global observation up to December (2004) Geneva, Switzerland: World Meteorological Organization.

van Zomeren, A., van der Laan, S. R., Kobesen, H. B. A., Huijgen, W. J. J., \& Comans, R. N. J. (2011). Changes in mineralogical and leaching properties of converter steel slag resulting from accelerated carbonation at low $\mathrm{CO}_{2}$ pressure. Waste Management, 3111, 2236-2244. DOI: 10.1016/j.wasman.2011.05.022. 